\title{
PERBANDINGAN KINERJA KEUANGAN ANTARA PERUSAHAAN ASURANSI, BANK, EFEK, DAN LEASING PERIODE 2007-2010
}

\author{
Nanik Linawati \\ Fakultas Ekonomi, Universitas Kristen Petra \\ Email: nanikl@peter.petra.ac.id
}

\begin{abstract}
Abstrak
Terjadi persaingan tinggi antar perusahaan keuangan untuk mendapatkan dana masyarakat akhir-akhir ini. Hal ini berdampak pada kinerja keuangan lembaga-lembaga tersebut. Studi ini bertujuan menguji perbedaan kinerja keuangan antara perusahaan asuransi, bank, efek, dan leasing, khususnya pada rasio keuangan. Alat statistik yang digunakan ialah Uji Beda Independent Sample. Hasil penelitian menunjukkan kinerja keuangan bank memiliki perbedaan signifikan dibandingkan dengan kinerja keuangan perusahaan lainnya, khususnya pada rasio keuangan PER, PBV, EPS, ROA, ROE, DAR, DER. Selain itu, tidak terdapat perbedaan signifikan pada kinerja keuangan antar perusahaan pada growth of revenue, net income growth.
\end{abstract}

Kata kunci: Kinerja keuangan, asuransi, bank, efek, leasing.

\begin{abstract}
There was high competition among financial companies to get funds from the society lately. It will have impacts on their financial performance. This study aimed to examine whether there was a difference in financial performance among bank, insurance, brokerage firm and leasing company, especially on financial ratios. The statistical tool used was independent sample $t$ test. The results showed bank had the most significant differences others, especially on PER, PBV, EPS, ROA, ROE, DAR, DER. Besides, there were no significant differences on financial ratios among them on growth of revenue and net income growth.
\end{abstract}

Keywords: Financial performance, insurance, bank, brokerage firm, leasing company.

\section{PENDAHULUAN}

Sektor keuangan merupakan salah satu sektor yang memiliki kontribusi yang positif terhadap pertumbuhan ekonomi Indonesia. Pada tahun 2011 sektor Keuangan, Real Estat, dan Jasa Perusahaan memiliki pertumbuhan sebesar 6,8\% lebih tinggi dibandingkan pertumbuhan PDB sebesar 6,5\%. Kemajuan sektor keuangan tidak dapat terlepas dari pencapaian prestasi yang diraih oleh institusi keuangan (Badan Pusat Statistik, 2012).

Pada dasarnya sebuah institusi keuangan bertindak sebagai agen yang menyediakan jasa keuangan untuk klien atau anggotanya. Institusi keuangan secara ketat diatur oleh pemerintah melalui peraturan keuangan. Tipe umum institusi keuangan meliputi bank, broker saham, asuransi dan bisnis keuangan sejenis.

Bank memiliki fungsi utama sebagai lembaga intermediasi, yaitu mentransfer dana dari penabung ke pihak peminjam dana dan memfasilitasi pembayaran barang dan jasa. Secara historis bank dikenal sebagai lembaga keuangan yang menawarkan berbagai jasa, mulai dari rekening koran, perencanaan tabungan hingga pinjaman untuk perusahaan, individu, dan pemerintah. Perkembangan terkini, menu jasa bank berkembang pesat menjadi investment banking (penjamin penerbitan sekuritas). Perlindungan asuransi, perencanaan keuangan, memberi advis untuk proses merger, penjualan jasa risk management untuk perusahaan dan individu dan berbagai jasa inovatif lain. Bank tidak lagi membatasi jasanya hanya pada produk tradisional namun sudah berkembang menjadi penyedia jasa keuangan umum (general financial-service providers). Perkembangan pesat bukan hanya dialami bank namun juga dialami para pesaing utama bank seperti asuransi, perusahaan broker (efek) dan leasing. Perusahaan-perusahaan ini berusaha untuk terus memperbaiki kinerjanya termasuk kinerja keuangannya, agar dapat bersaing dengan bank (Rose \& Hudgins, 2008). 
Upaya perusahaan asuransi untuk menghimpun dana masyarakat, nampak dari produk-produk dengan karakteristik kombinasi antara proteksi dan investasi, yang dikenal dengan unit-link. Perusahaan broker berupaya menjaring dana masyarakat melalui penawaran berbagai produk investasi yang ditransaksikan di pasar modal, seperti saham dan obligasi. Sedangkan perusahaan leasing berupaya menghimpun dana masyarakat melalui pembiayaan pembelian kendaraan bermotor dengan fasilitas kredit.

Semakin ketatnya persaingan antara perusahaan asuransi, bank, perusahaan efek, dan perusahaan leasing dalam mendapatkan dana dan menyalurkan dana akan mendorong perusahaan untuk mencapai kinerja keuangan yang terbaik, agar tetap mendapatkan kepercayaan dari para investor (Yudha \& Nasir, 2012). Penelitian ini difokuskan pada uji perbedaan kinerja keuangan antar perusahaan asuransi, bank, efek, dan leasing tanpa menunjukkan antar lembaga keuangan tersebut lebih baik daripada yang lain.

Berkaitan dengan fenomena tersebut perlu dikaji lebih jauh, ada atau tidaknya perbedaan kinerja keuangan antara perusahaan asuransi, bank, efek, dan leasing, khususnya pada rasio keuangan Price Earning Ratio (PER), Price to Book Value (PBV), Earning Per Share (EPS), Return on Asset (ROA), Return on Equity (ROE), Debt to Total Asset Ratio (DAR), Debt to Total Equity Ratio (DER), growth of revenue, dan net income growth.

\section{LANDASAN TEORI DAN HIPOTESIS}

\section{Kinerja Bank dan Para Pesaing Utama}

Perkembangan terkini kondisi pada lembaga keuangan menunjukkan bahwa bankir dan para pesaingnya berada di bawah tekanan yang sangat besar agar mampu memiliki kinerja yang baik di setiap periode (Rose \& Hudgins, 2008).

Kinerja bagi lembaga keuangan merujuk pada cara lembaga keuangan secara memadai mampu memenuhi kebutuhan para pemegang saham, pekerja, deposan dan kreditur lain, serta customer yang memerlukan pinjaman. Pada saat yang bersamaan lembaga keuangan juga harus menemukan cara untuk memenuhi ketentuan pemerintah, baik dalam kebijakan operasional, utang, investasi

\section{Keterkaitan antar Lembaga-lembaga Keuangan}

Bank-bank bersaing dengan lembaga keuangan lain dalam hal penghimpunan dana baik yang berasal dari individu maupun dari perusahaan (Groose, 2004).
Selain itu bank juga berkompetisi dengan lembaga keuangan lain dalam hal penyaluran pinjaman, misalnya bank menawarkan kredit mobil, perusahaan pembiayaan juga menawarkan jasa yang sama. Bank menawarkan deposito dengan suku bunga tertentu, Perusahaan Reksadana menawarkan produk investasi Reksadana Pasar Uang, Reksadana, Pendapatan Tetap, Reksadana Campuran, maupun Reksadana Saham yang memberikan imbal hasil yang lebih tinggi dari suku bunga deposito.

Lembaga-lembaga keuangan selain melakukan upaya penghimpunan dana, lembaga ini juga terus berupaya secara berkesinambungan untuk meningkatkan kinerja keuangan dan berupaya dapat tampil pada posisi peringkat yang tinggi di ajang publikasi pemeringkatan kinerja keuangan lembaga keuangan yang difasilitasi oleh media keuangan. (Nuryanti, 2010)

\section{Kerangka Konseptual dan Hipotesis Penelitian}

Persaingan antar institusi keuangan menunjukkan intensitas yang semakin tinggi sejalan dengan semakin berkembangnya penggunaan internet untuk memasarkan produk jasa keuangan dan sekaligus untuk melayani para customer (Madura, 2008). Hal serupa juga dikemukakan oleh World Economic Forum yang menyatakan terjadinya krisis keuangan global tahun 2007 memaksa lembaga-lembaga keuangan untuk berupaya agar mampu bertahan di tengah persaingan yang terjadi di pasar keuangan (World Economic Forum, 2011). Semakin ketatnya persaingan haruslah diimbangi dengan kinerja keuangan yang baik. Penelitian ini ingin mengetahui apakah persaingan yang terjadi antar lembaga keuangan mengakibatkan adanya perbedaan kinerja keuangan atau tidak, tanpa menduga bahwa lembaga keuangan tertentu lebih baik daripada yang lain. Dengan demikian hipotesa yang akan diuji dalam penelitian ini adalah sebagai berikut:

H1a: Terdapat perbedaan kinerja keuangan (PER, PBV, EPS, ROA, ROE, DAR, DER, Growth of Revenue, Net Income Growth) yang signifikan antara perusahaan asuransi dan bank

H1b: Terdapat perbedaan kinerja keuangan (PER, PBV, EPS, ROA, ROE, DAR, DER, Growth of Revenue, Net Income Growth) yang signifikan antara perusahaan asuransi dan perusahaan efek.

H1c: Terdapat perbedaan kinerja keuangan (PER, PBV, EPS, ROA, ROE, DAR, DER, Growth of Revenue, Net Income Growth) yang signifikan antara perusahaan asuransi dan perusahaan leasing. 
H1d: Terdapat perbedaan kinerja keuangan (PER, PBV, EPS, ROA, ROE, DAR, DER, Growth of Revenue, Net Income Growth) yang signifikan antara perusahaan bank dan perusahaan efek

H1e: Terdapat perbedaan kinerja keuangan (PER, PBV, EPS, ROA, ROE, DAR, DER, Growth of Revenue, Net Income Growth) yang signifikan antara perusahaan bank dan perusahaan leasing.

H1f: Terdapat perbedaan kinerja keuangan (PER, PBV, EPS, ROA, ROE, DAR, DER, Growth of Revenue, Net Income Growth) yang signifikan antara perusahaan efek dan perusahaan leasing.

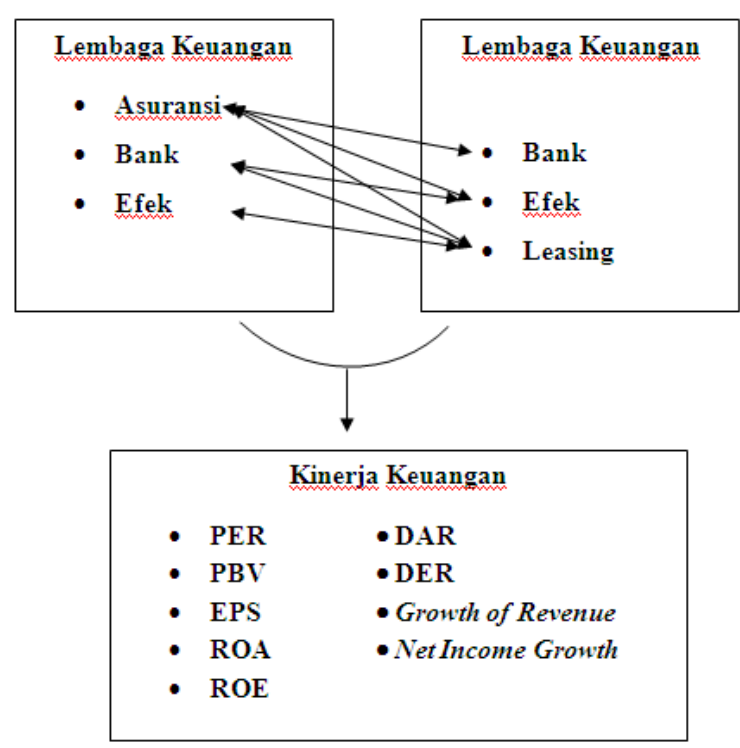

Gambar 1. Kerangka Perbandingan Kinerja Keuangan Antar Lembaga Keuangan

Penelitian ini ingin menguji ada atau tidaknya perbedaan kinerja keuangan antara perusahaan asuransi, bank, efek, dan leasing, khususnya pada rasio keuangan Price Earning Ratio (PER), Price to Book Value (PBV), Earning Per Share (EPS), Return on Asset (ROA), Return on Equity (ROE), Debt to Total Asset Ratio (DAR), Debt to Total Equity Ratio (DER), growth of revenue, dan net income growth.

\section{METODE PENELITIAN}

\section{Populasi dan Sampel Penelitian}

Populasi dalam penelitian ini adalah semua saham-saham industri keuangan pada subsektor asuransi, bank, efek, dan leasing tahun 2007-2010, dengan menggunakan data tahunan yang diperoleh dari Laporan Keuangan Tahunan Bursa Efek
Indonesia, yang diunduh dari www idx.co.id. Periode penelitian diambil berdasarkan ketersediaan data pada internet. Sedangkan pengambilan sampel didasarkan pada kelengkapan data yang dimiliki secara runtut selama periode penelitian.

\section{Deskripsi Variabel Penelitian}

Variabel dalam penelitian ini adalah rasio keuangan yang meliputi: Price Earning Ratio (PER), Price to Book Value (PBV), Earning Per Share (EPS), Return on Asset (ROA), Return on Equity (ROE), Debt to Total Asset Ratio (DAR), Debt to Total Equity Ratio (DER), growth of revenue, dan net income growth dari perusahaan asuransi, bank, efek, dan leasing. Masing-masing rasio keuangan antar kelompok perusahaan diuji untuk membuktikan ada atau tidaknya perbedaan kinerja keuangan yang signifikan antar perusahaan. Berdasarkan Brigham \& Daves (2010), berikut ini diuraikan lebih lanjut tentang rasio-rasio keuangan yang diteliti.

\section{PER}

Price Earnings Ratio menunjukkan seberapa besar investor bersedia untuk membayar selembar saham untuk setiap Rupiah laba bersih yang dihasilkan oleh perusahaan. Price Earning Ratio yang lebih besar menunjukkan kinerja keuangan yang lebih baik, karena kesediaan investor yang lebih besar dalam membayar setiap lembar saham untuk setiap Rupiah laba bersih yang dihasilkan oleh perusahaan. Price Earnings Ratio dihitung dengan rumus:

Price Earning Ratio $=\frac{\text { Harga per lembar saham }}{\text { Lababersih per lembar saham }}$

\section{2. $P B V$}

Price Book Value atau Price to Book Ratio merupakan rasio yang digunakan untuk membandingkan harga pasar sebuah saham terhadap nilai bukunya. Price Book Value yang lebih besar menunjukkan kinerja keuangan yang lebih baik, karena harga pasar sebuah saham terhadap nilai bukunya lebih besar dibandingkan saham yang lain. Price Book Value dihitung dengan rumus:

Price Book Value $=\frac{\text { Harga per lembar saham }}{\text { Nilai buku per lembar saham }}$

\section{Earnings Per Share (EPS)}

Earnings Per Share (EPS) menunjukkan bagian dari laba perusahaan yang tersedia untuk setiap 
lembar saham. Earnings Per Share yang lebih besar menunjukkan kinerja keuangan yang lebih baik, karena bagian yang lebih besar dari laba perusahaan yang tersedia untuk setiap lembar saham. Earnings Per Share (EPS) dihitung dengan rumus:

$$
\text { Earnings Per Share }(\text { EPS })=\frac{\text { Laba bersih }}{\text { Jumlah lembar saham beredar }}
$$

\section{4. $R O A$}

Return on Total Asset menunjukkan kemampuan perusahaan dalam menghasilkan keuntungan dengan menggunakan keseluruhan aset yang dimiliki. Return on Total Asset yang lebih besar menunjukkan kinerja keuangan yang lebih baik, karena menunjukkan kemampuan perusahaan yang lebih besar dalam menghasilkan keuntungan dengan menggunakan keseluruhan aset yang dimiliki. Rumus untuk menghitung $R O A$ adalah:

$R O A=\frac{\text { Earning after tax }}{\text { Total asset }}$

\section{Return on equity (ROE)}

Return on equity mengukur kemampuan perusahaan dalam menghasilkan keuntungan dengan modal sendiri. Return on equity yang lebih besar menunjukkan kinerja keuangan yang lebih baik, karena menunjukkan kemampuan perusahaan yang lebih besar dalam menghasilkan keuntungan dengan modal sendiri. Rumus untuk menghitung $R O E$ adalah:

$$
R O E=\frac{\text { Earning after tax }}{\text { Total equity }}
$$

\section{Debt to Total Aset Ratio (DAR)}

Debt to Total Aset Ratio adalah perbandingan jumlah hutang dengan keseluruhan asset yang dimiliki perusahaan yang mengukur persentase penggunaan dana yang berasal dari kreditur dibanding keseluruhan aset. Apabila diterapkan pada industri atau subsektor yang sama, Debt to Total Aset Ratio yang lebih besar menunjukkan kinerja keuangan yang lebih buruk karena menunjukkan ketergantungan yang lebih besar dalam penggunaan utang terhadap keseluruhan asset yang dimiliki perusahaan. Namun dalam penelitian ini, membandingkan Debt to Total Aset Ratio antar subsektor tidak layak untuk dilakukan, karena setiap subsektor memiliki karakteristik yang spesifik. Rumus untuk menghitung $D A R$ adalah:
Debt to Total Aset Ratio $(D A R)=\frac{\text { Total liabilitie } s}{\text { Total assets }}$

\section{Debt to Equity Ratio (DER)}

Debt to Equity Ratio adalah perbandingan jumlah hutang dengan modal sendiri yang mengukur persentase penggunaan dana yang berasal dari kreditur dibanding modal sendiri. Apabila diterapkan pada industri atau subsektor yang sama, Debt to Equity Ratio yang lebih besar menunjukkan kinerja keuangan yang lebih buruk karena menunjukkan ketergantungan yang lebih besar dalam penggunaan utang terhadap modal sendiri yang dimiliki perusahaan. Namun dalam penelitian ini, membandingkan Debt to Equity Ratio antar subsektor tidak layak untuk dilakukan, karena setiap subsektor memiliki karakteristik yang spesifik. Rumus untuk menghitung DER adalah:

Debt to Equity Ratio $=\frac{\text { Total liabilities }}{\text { Total owner equity }}$

\section{Growth of Revenue}

Revenue merupakan hasil kali antara unit penjualan dengan harga per unit. Revenue perusahaan dapat bertumbuh akibat dari Marketing Mix, baik promosi, saluran distribusi dan elemen pemasaran yang lain. Growth of Revenue yang lebih besar menunjukkan kinerja keuangan yang lebih baik, karena menunjukkan kemampuan perusahaan yang lebih besar dalam menumbuhkan pendapatannya. Growth of Revenue dihitung dengan rumus:

Growth of Revenue $=\frac{\text { Reveneue }_{t}-\text { Revenue }_{t-1}}{\text { Revenue }_{t-1}}$

\section{Net Income Growth}

Net Income Growth menunjukkan pertumbuhan laba bersih tahunan bagi sebuah saham. Net Income Growth memberikan gambaran seberapa baik tingkat pertumbuhan laba bersih sebuah perusahaan. Net Income Growth yang lebih besar menunjukkan kinerja keuangan yang lebih baik, karena menunjukkan kemampuan perusahaan yang lebih besar dalam menumbuhkan laba bersih tahunan bagi sebuah saham. Net Income Growth dihitung dengan rumus:

Net Income Growth $=\frac{\text { Lababersih }_{t}-\text { Laba bersih }_{t-1}}{\text { Laba bersih }_{t-1}}$ 


\section{Teknik Analisis}

Pendekatan dalam penelitian ini menggunakan Uji Beda Independent Sample dengan program SPSS 13.0 untuk membuktikan apakah terdapat perbedaan yang signifikan antara kinerja keuangan perusahaan asuransi, bank, efek, dan leasing. Data yang telah berdistribusi normal diuji dengan Independent sample t-test, sedangkan data yang tidak berdistribusi normal digunakan Man Whitney U-test.

\section{HASIL PENELITIAN DAN PEMBAHASAN}

\section{Analisis Deskriptif}

\section{Price Earning Ratio (PER) tahun 2007-2010}

Tabel 1. Deskripsi Price Earning Ratio (PER) Perusahaan Pada Industri Keuangan Tahun 2007-2010

\begin{tabular}{lcc}
\hline \multicolumn{1}{c}{ Perusahaan } & Rata-rata & Deviasi Standar \\
\hline Asuransi & 4,19 & 2,43 \\
Bank & 13,18 & 5,05 \\
Efek & 12,53 & 10,55 \\
Leasing & 6,25 & 3,86 \\
\hline
\end{tabular}

Rata-rata PER terbesar dimiliki oleh bank sebesar 13,18. Hal ini menginformasikan bahwa kesediaan investor untuk membeli saham bank per rupiah laba bersih yang dihasilkan lebih besar dari kesediaan investor untuk membeli saham efek, leasing, maupun asuransi.

\section{Price to Book Value (PBV) tahun 2007-2010}

Tabel 2. Deskripsi Price To Book Value (PBV) Perusahaan Pada Industri Keuangan Tahun 2007-2010

\begin{tabular}{lcc}
\hline Perusahaan & Rata-rata & Deviasi Standar \\
\hline Asuransi & 0,598 & 0,257 \\
Bank & 1,716 & 0,921 \\
Efek & 1,441 & 0,524 \\
Leasing & 1,136 & 0,785 \\
\hline
\end{tabular}

Rata-rata PBV terbesar dimiliki oleh perusahaan bank sebesar 1,716. Hal ini menginformasikan bahwa kesediaan investor untuk membeli saham bank per rupiah nilai buku lebih besar dari kesediaan investor untuk membeli saham efek, leasing, maupun asuransi.

Rata-rata PBV perusahaan asuransi merupakan yang terkecil dan bernilai di bawah satu. Hal ini mengindikasikan investor tidak berminat membeli saham perusahaan asuransi. Kondisi ini dipicu ketatnya persaingan di industri asuransi serta perusahaan asuransi nasional belum mampu menandingi perusahaan asuransi asing yang memiliki aset yang jauh lebih besar dan strategi pemasaran yang lebih baik.

\section{Earning Per Share (EPS) tahun 2007-2010}

Tabel 3. Deskripsi Earning Per Share (EPS) Perusahaan Pada Industri Keuangan Tahun 2007-2010

\begin{tabular}{lcc}
\hline Perusahaan & Rata-rata & Deviasi Standar \\
\hline Asuransi & 52,865 & 31,980 \\
Bank & 201,982 & 150,438 \\
Efek & 20,375 & 13,939 \\
Leasing & 46,841 & 20,357 \\
\hline
\end{tabular}

Rata-rata EPS terbesar dimiliki oleh bank sebesar 201,982. Hal ini menginformasikan bahwa laba bersih per lembar saham bank lebih besar dari laba bersih per lembar saham efek, leasing, maupun asuransi.

\section{Return on Asset (ROA) tahun 2007-2010}

Tabel 4. Deskripsi Return on Asset (ROA) Perusahaan Pada Industri Keuangan Tahun 2007-2010

\begin{tabular}{lcc}
\hline Perusahaan & Rata-rata (\%) & Deviasi Standar \\
\hline Asuransi & 7,15 & 2,026 \\
Bank & 1,73 & 0,87 \\
Efek & 5,34 & 3,35 \\
Leasing & 12,68 & 10,31 \\
\hline
\end{tabular}

Rata-rata ROA terbesar dimiliki oleh perusahaan leasing sebesar $12,68 \%$. Hal ini menginformasikan bahwa kemampuan perusahaan leasing untuk menghasilkan laba bersih dengan menggunakan total aset yang dimilikinya lebih besar dari kemampuan perusahaan bank, efek, maupun asuransi.

\section{Return on Equity (ROE) tahun 2007-2010}

Tabel 5. Deskripsi Return on Equity (ROE) Perusahaan Pada Industri Keuangan Tahun 2007-2010

\begin{tabular}{lcc}
\hline Perusahaan & Rata-rata $(\%)$ & Deviasi tandar \\
\hline Asuransi & 17,18 & 5,98 \\
Bank & 17,34 & 8,93 \\
Efek & 16,36 & 9,33 \\
Leasing & 23,68 & 19,09 \\
\hline
\end{tabular}

Rata-rata ROE terbesar dimiliki oleh leasing sebesar 23,68\%. Hal ini menginformasikan bahwa kemampuan perusahaan leasing untuk menghasilkan laba bersih dengan menggunakan total equity yang dimilikinya lebih besar dari kemampuan perusahaan bank, efek, maupun asuransi. 
6. Debt to Total Asset Ratio (DAR) tahun 2007-2010

Tabel 6. Deskripsi Debt To Total Asset Ratio (DAR) Perusahaan Pada Industri Keuangan Tahun 2007-2010

\begin{tabular}{lcc}
\hline Perusahaan & Rata-rata & Deviasi Standar \\
\hline Asuransi & 0,50 & 0,16 \\
Bank & 0,90 & 0,03 \\
Efek & 0,67 & 0,09 \\
Leasing & 0,54 & 0,22 \\
\hline
\end{tabular}

Rata-rata DAR terbesar dimiliki oleh perusahaan bank sebesar 0,90. Hal ini menginformasikan bahwa proporsi utang terhadap total aset perusahaan bank lebih besar dari proporsi utang terhadap total aset perusahaan asuransi, efek, maupun leasing.

Rata-rata $D A R$ terbesar dimiliki oleh Perusahaan Bank, hal ini disebabkan peran utama Perusahaan Bank, yaitu menghimpun dana atau berutang pada para nasabah, sedangkan rata-rata $D A R$ terkecil dimiliki oleh perusahaan Asuransi. Kecilnya rata-rata $D A R$ Perusahaan Asuransi terkait dengan aktivitas utama perusahaan ini, yang hanya fokus pada pengumpulan premi dan berusaha menginvestasikannya pada produk investasi yang produktif.

7. Debt to Total Equity Ratio (DER) tahun 20072010

Tabel 7. Deskripsi Debt To Total Equity Ratio (DER) Perusahaan Pada Industri Keuangan Tahun 2007-2010

\begin{tabular}{lcc}
\hline Perusahaan & Rata-rata & Deviasi Standar \\
\hline Asuransi & 1,33 & 0,85 \\
Bank & 9,45 & 2,81 \\
Efek & 2,25 & 1,05 \\
Leasing & 0,77 & 0,37 \\
\hline
\end{tabular}

Rata-rata DER terbesar dimiliki oleh perusahaan bank sebesar 9,45. Hal ini menginformasikan bahwa proporsi utang terhadap total equity perusahaan bank lebih besar dari proporsi utang terhadap total equity perusahaan asuransi, efek, maupun leasing.

Rata-rata $D E R$ terbesar dimiliki oleh perusahaan Bank, karena aktivitas utama Bank adalah menghimpun (meminjam) dana dari Surplus Economic Unit atau masyarakat yang kelebihan dana dan menyalurkannya ke Deficit Economic Unit atau pihak yang memerlukan dana. Sehingga dapat dipahami jika perusahaan Bank memiliki DER terbesar dibanding Asuransi, Efek, dan Leasing. Sedangkan $D E R$ terkecil dimiliki oleh Perusahaan Leasing. Kecilnya DER Leasing disebabkan aktivitas Leasing yang utama, yaitu memberi pinjaman kepada masyarakat.

8. Growth of Revenue tahun 2007-2010

Tabel 8. Deskripsi Growth of Revenue Perusahaan Pada Industri Keuangan Tahun 2007-2010

\begin{tabular}{lcc}
\hline Perusahaan & Rata-rata & Deviasi Standar \\
\hline Asuransi & 0,10 & 0,18 \\
Bank & 0,14 & 0,19 \\
Efek & 0,31 & 0,95 \\
Leasing & 0,20 & 0,29 \\
\hline
\end{tabular}

Rata-rata Growth of Revenue terbesar dimiliki oleh perusahaan Efek sebesar 0,31. Kondisi ini disumbang oleh kenaikan IHSG, khususnya antara Januari 2009-September 2010 IHSG bertumbuh sekitar 154\% (Darmawan, 2010). Sedangkan Growth of Revenue terkecil dimiliki oleh perusahaan Asuransi. Kondisi ini disebabkan ketatnya peta

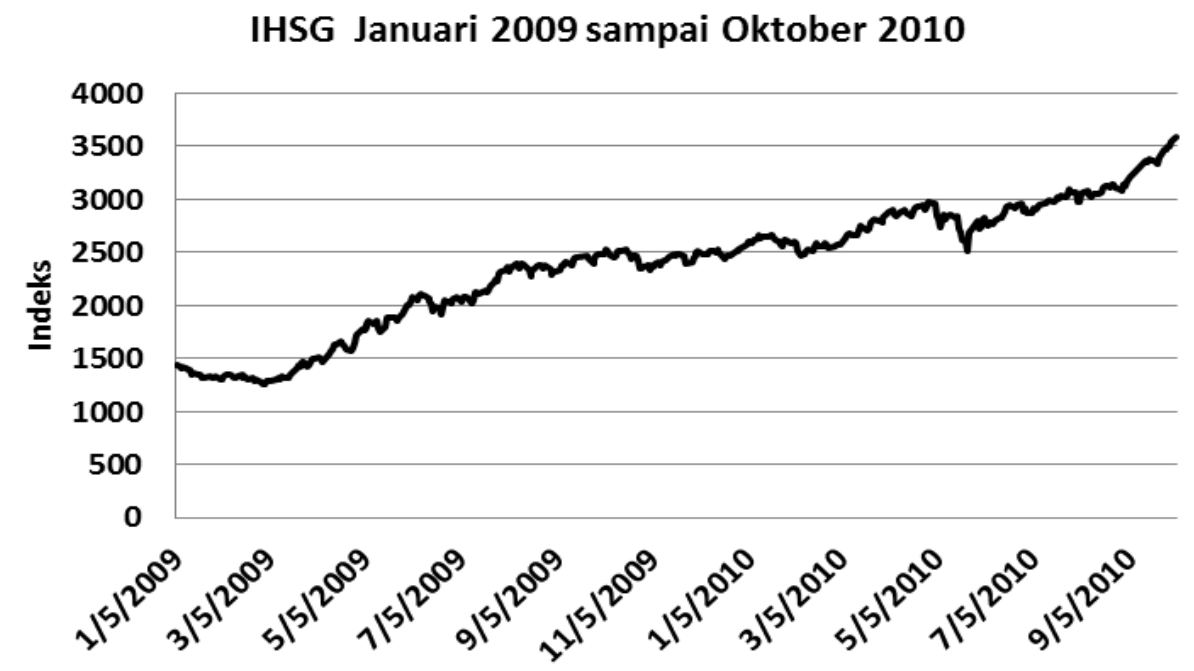

Gambar 2. Perkembangan IHSG Pada Januari 2009 Sampai Oktober 2010 
persaingan yang terjadi di industri perusahaan Asuransi baik antar perusahaan Asuransi Nasional dengan perusahaan Asuransi asing. Maupun antar perusahaan Asuransi Nasional. (Meryana, 2011).

\section{Net Income Growth tahun 2007-2010}

Tabel 9. Deskripsi Net Income Growth Perusahaan Pada Industri Keuangan Tahun 2007-2010

\begin{tabular}{lcc}
\hline Perusahaan & Rata-rata & Deviasi Standar \\
\hline Asuransi & 0,45 & 0,20 \\
Bank & 0,19 & 0,43 \\
Efek & 0,59 & 1,57 \\
Leasing & 0,21 & 0,33 \\
\hline
\end{tabular}

Rata-rata Net Income Growth terbesar dimiliki oleh perusahaan Efek, Net Income Growth, yaitu sebesar 0,59 atau 59 persen. Prestasi ini disumbang oleh kenaikan Indeks pasar antara Januari 2009September 2010 seperti yang nampak pada Gambar 2, pada saat itu IHSG bertumbuh sekitar $154 \%$ (Darmawan, 2010).

\section{Analisis Uji Beda Rasio Keuangan Antar Perusahaan Keuangan}

Uji beda dilakukan dengan menggunakan General Linear Model Univariate dengan alpha $5 \%$ dan $10 \%$. Uji ini diterapkan pada sampel yang tidak berpasangan. Hasil uji memperoleh hasil sebagai berikut:

\section{Price Earning Ratio (PER)}

Perusahaan keuangan yang memiliki perbedaan yang signifikan pada PER, yaitu antara: Asuransi dan Bank, Asuransi dan Efek, Bank dan Leasing, Efek dan Leasing.

Sedangkan antar perusahaan keuangan yang tidak memiliki perbedaan yang signifikan pada PER, yaitu antara: Asuransi dan Leasing, Bank dan Efek.

2. Price to Book Value (PBV)

Perusahaan keuangan yang memiliki perbedaan yang signifikan pada PBV, yaitu antara: Asuransi dan Bank, Asuransi dan Efek, Bank dan Leasing. Sedangkan pada alpha $(\alpha)=10 \%$ perusahaan Asuransi dan Leasing memiliki perbedaan yang signifikan.

Sementara, perusahaan keuangan yang tidak memiliki perbedaan yang signifikan pada PBV, yaitu antara: Bank dan Efek serta antara perusahaan Efek dan Leasing

3. Earning Per Share (EPS)

Antar perusahaan keuangan yang memiliki perbedaan yang signifikan pada EPS, yaitu antara:
Asuransi dan Bank, Bank dan Efek, Bank dan Leasing.

Sedangkan perusahaan keuangan yang tidak memiliki perbedaan yang signifikan pada EPS, yaitu antara: Asuransi dan Efek, Asuransi dan Leasing, serta antara Efek dan Leasing

4. Return on Asset (ROA)

Perusahaan keuangan yang memiliki perbedaan yang signifikan pada ROA, yaitu antara: Asuransi dan Bank, Asuransi dan Leasing, Bank dan Efek, Bank dan Leasing, serta Efek dan Leasing.

Sedangkan perusahaan keuangan yang tidak memiliki perbedaan yang signifikan pada ROA, yaitu antara: Asuransi dan Efek.

5. Return on Equity (ROE)

Antar perusahaan keuangan yang memiliki perbedaan yang signifikan pada ROE, yaitu antara: Bank dan Efek, serta Efek dan Leasing (alpha $(\alpha)$ $=10 \%)$.

Sedangkan antar perusahaan keuangan yang tidak memiliki perbedaan yang signifikan pada ROE, yaitu antara: Asuransi dan Bank, Asuransi dan Efek, Asuransi dan Leasing serta Bank dan Efek.

6. Debt to Total Asset Ratio (DAR)

Perusahaan keuangan yang memiliki perbedaan yang signifikan pada DAR, yaitu antara: Asuransi dan Bank, Asuransi dan Efek, Bank dan Efek, Bank dan Leasing, serta Efek dan Leasing.

Sedangkan perusahaan keuangan yang tidak memiliki perbedaan yang signifikan pada DAR, yaitu antara: Asuransi dan Leasing.

7. Debt to Total Equity Ratio (DER)

Perusahaan keuangan yang memiliki perbedaan yang signifikan pada DER, yaitu antara: Asuransi dan Bank, Bank dan Efek, serta Bank dan Leasing Sedangkan perusahaan keuangan yang tidak memiliki perbedaan yang signifikan pada DER, yaitu antara: Asuransi dan Efek, Asuransi dan Leasing, serta Efek dan Leasing.

8. Growth of Revenue

Tidak ada perusahaan keuangan yang memiliki perbedaan yang signifikan pada Growth of Revenue, baik antara: Asuransi dan Bank, Asuransi dan Efek, Asuransi dan Leasing, Bank dan Efek, Bank dan Leasing serta Efek dan Leasing.

9. Net Income Growth

Tidak ada perusahaan keuangan yang memiliki perbedaan yang signifikan pada Net Income Growth, baik antara: Asuransi dan Bank, Asuransi dan Efek, Asuransi dan Leasing, Bank dan Efek, Bank dan Leasing serta Efek dan Leasing. 


\section{Ringkasan Hasil}

Tabel berikut ini menyajikan hasil ringkasan hasil uji beda rasio keuangan PER, PBV, EPS, ROA, $\mathrm{ROE}, \mathrm{DAR}, \mathrm{DER}$, growth of revenue, serta net income growth antara asuransi dan bank, asuransi dan efek, asuransi dan leasing, bank dan efek, bank dan leasing, serta efek dan leasing periode 2007-2010.

Tabel 10. Ringkasan Hasil Uji Beda Rasio Keuangan PER, PBV, EPS, ROA, ROE, DAR, DER, Growth of Revenue, serta Net Income Growth Tahun 2007-2010

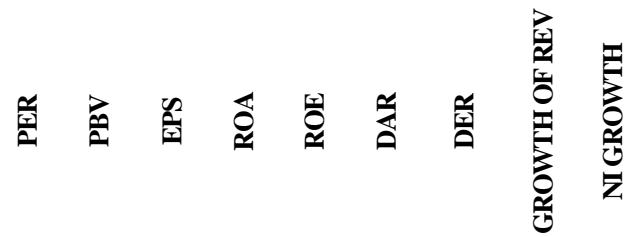

\begin{tabular}{|c|c|c|c|c|c|c|c|c|}
\hline $\begin{array}{l}\text { Asuransi- } \\
\text { Bank }\end{array}$ & Sig** & Sig** & Sig** & Sig** & $\begin{array}{c}\text { Tidak } \\
\text { Sig }\end{array}$ & Sig** & Sig** & $\begin{array}{c}\text { Tidak } \\
\text { Sig }\end{array}$ \\
\hline Asuransi & $\mathrm{Sig}^{* *}$ & Sig** & Tidak & Tidak & Tidak & Sig** & Tidak & Tidak \\
\hline Efek & & & $\mathrm{Sig}$ & Sig & Sig & & Sig & Sig \\
\hline Asuransi- & Tidak & Sig* & Tidak & $\mathrm{Sig}^{* * *}$ & Tidak & Tidak & Tidak & Tidak \\
\hline Leasing & Sig & & Sig & & Sig & Sig & Sig & Sig \\
\hline Bank-Ëfek & $\begin{array}{c}\text { Tidak } \\
\text { Sig }\end{array}$ & $\begin{array}{c}\text { Tidak } \\
\text { Sig }\end{array}$ & Sig** & Sig** & $\begin{array}{c}\text { Tidak } \\
\text { Sig }\end{array}$ & $\mathrm{Sig}^{* *}$ & Sig** & $\begin{array}{c}\text { Tidak } \\
\text { Sig }\end{array}$ \\
\hline $\begin{array}{l}\text { Bank- } \\
\text { Leasing }\end{array}$ & Sig** & Sig** & $\mathrm{Sig}^{* *}$ & Sig** & Sig* & Sig** & Sig** & $\begin{array}{c}\text { Tidak } \\
\text { Sig }\end{array}$ \\
\hline $\begin{array}{l}\text { Efek- } \\
\text { Leasing }\end{array}$ & Sig** & $\begin{array}{c}\text { Tidak } \\
\text { Sig }\end{array}$ & $\begin{array}{c}\text { Tidak } \\
\text { Sig }\end{array}$ & Sig** & Sig* & Sig** & $\begin{array}{c}\text { Tidak } \\
\text { Sig }\end{array}$ & $\begin{array}{c}\text { Tidak } \\
\text { Sig }\end{array}$ \\
\hline
\end{tabular}

\section{Price Earning Ratio (PER)}

Perbedaan PER yang signifikan pada alpha $(\alpha)=$ 5\%, yaitu antara: Asuransi-Bank, Asuransi-Efek, Bank-Leasing, serta Efek-Leasing. Sedangkan antara Asuransi-Leasing, serta Bank-Efek tidak memiliki perbedaan PER yang signifikan.

2. Price to Book Value (PBV)

Perbedaan PBV yang signifikan pada alpha $(\alpha)=$ 5\%, yaitu antara: Asuransi-Bank, Asuransi-Efek, serta Bank-Leasing. Sedangkan Asuransi-Leasing memiliki perbedaan PBV yang signifikan pada alpha $(\alpha)=10 \%$. Sedangkan antara Bank-Efek serta Efek-Leasing tidak memiliki perbedaan PBV yang signifikan.

3. Earning Per Share (EPS)

Perbedaan EPS yang signifikan pada alpha $(\alpha)=$ $5 \%$, yaitu antara: Asuransi-Bank, Bank-Efek, Bank-Leasing. Sedangkan antara Asuransi-Efek, Asuransi-Leasing, serta Efek-Leasing tidak memiliki perbedaan EPS yang signifikan.

4. Return on Asset (ROA)

Perbedaan ROA yang signifikan pada alpha $(\alpha)=$ $5 \%$, yaitu antara: Asuransi-Bank, AsuransiLeasing, Bank-Efek, Bank-Leasing, serta EfekLeasing. Sedangkan antara Asuransi-Efek tidak memiliki perbedaan ROA yang signifikan.

\section{Return on Equity (ROE)}

Perbedaan ROE, yang signifikan pada alpha $(\alpha)=$ $10 \%$, yaitu antara: Bank-Efek, serta EfekLeasing. Sedangkan antara Asuransi-Bank, Asuransi-Efek, Asuransi-Leasing serta Bank-Efek yang tidak memiliki perbedaan ROE yang signifikan.

\section{Debt to Total Asset Ratio (DAR)}

Perbedaan DAR yang signifikan pada alpha $(\alpha)=$ 5\%, yaitu antara: Asuransi-Bank, Asuransi-Efek, Bank-Efek, Bank-Leasing, serta Efek-Leasing. Sedangkan antara Asuransi-Leasing tidak memiliki perbedaan DAR yang signifikan.

\section{Debt to Total Equity Ratio (DER)}

Perbedaan DER yang signifikan pada alpha $(\alpha)=$ $5 \%$, yaitu antara: Asuransi-Bank, Bank-Efek, serta Bank-Leasing. Sedangkan antara Asuransi-Efek, Asuransi-Leasing, serta Efek-Leasing tidak memiliki perbedaan DER yang signifikan.

8. Growth of Revenue

Tidak ada lembaga keuangan yang memiliki perbedaan Growth of Revenue yang signifikan.

9. Net Income Growth

Tidak ada lembaga keuangan yang memiliki perbedaan Net Income Growth yang signifikan. Perbedaan rasio keuangan terbanyak terdapat antara perusahaan Bank dan Leasing, yang berbeda secara signifikan pada rasio keuangan PER, PBV, EPS, ROA, ROE, DAR, serta DER.

Tabel 11. Ringkasan Selisih Rata-rata Rasio Keuangan PER, PBV, EPS, ROA, ROE, DAR, DER antara Bank dan Leasing Tahun 2007-2010

\begin{tabular}{|c|c|c|}
\hline $\begin{array}{c}\text { Rasio } \\
\text { Keuangan }\end{array}$ & $\begin{array}{c}\text { Selisih } \\
\text { Rata-rata }\end{array}$ & Keterangan \\
\hline PER & 6,9 & $\begin{array}{l}\text { PER bank lebih baik daripada } \\
\text { leasing }\end{array}$ \\
\hline PBV & 0,6 & $\begin{array}{l}\text { PBV bank lebih baik daripada } \\
\text { leasing }\end{array}$ \\
\hline EPS & 155,1 & $\begin{array}{l}\text { EPS bank lebih baik daripada } \\
\text { leasing }\end{array}$ \\
\hline ROA & $-10,9$ & $\begin{array}{l}\text { ROA leasing lebih baik daripada } \\
\text { bank }\end{array}$ \\
\hline ROE & $-6,33$ & $\begin{array}{l}\text { ROE leasing lebih baik daripada } \\
\text { bank }\end{array}$ \\
\hline DAR & 0,4 & $\begin{array}{l}\text { DAR bank lebih tinggi daripada } \\
\text { leasing }\end{array}$ \\
\hline DER & 8,7 & $\begin{array}{l}\text { DER bank lebih tinggi daripada } \\
\text { leasing }\end{array}$ \\
\hline
\end{tabular}

Pada selisih rata-rata rasio keuangan PER, PBV, dan EPS, bank lebih baik daripada leasing. Sedangkan selisih rata-rata rasio keuangan ROA dan ROE leasing lebih baik daripada bank. Pada selisih rata-rata rasio keuangan DAR dan DER, bank lebih 
tinggi daripada leasing, karena aktivitas utama bank, yaitu menghimpun dana masyarakat atau berutang untuk kemudian disalurkan kepada pihak yang memerlukan dana.

Selanjutnya pada urutan kedua, antara perusahaan Bank dan Asuransi berbeda signifikan pada rasio keuangan PER, PBV, EPS, ROA, DAR, serta DER.

Tabel 12. Ringkasan Selisih Rata-rata Rasio Keuangan PER, PBV, EPS, ROA, DAR, DER antara Bank dan Asuransi Tahun 2007-2010

\begin{tabular}{|c|c|c|}
\hline $\begin{array}{c}\text { Rasio } \\
\text { Keuangan }\end{array}$ & $\begin{array}{c}\text { Selisih } \\
\text { Rata-rata }\end{array}$ & Keterangan \\
\hline PER & 9,0 & $\begin{array}{l}\text { PER bank lebih baik daripada } \\
\text { asuransi }\end{array}$ \\
\hline PBV & 1,1 & $\begin{array}{l}\text { PBV bank lebih baik daripada } \\
\text { asuransi }\end{array}$ \\
\hline EPS & 149,1 & $\begin{array}{l}\text { EPS bank lebih baik daripada } \\
\text { asuransi }\end{array}$ \\
\hline ROA & $-5,4$ & $\begin{array}{l}\text { ROA asuransi lebih baik } \\
\text { daripada bank }\end{array}$ \\
\hline ROE & 0,2 & $\begin{array}{l}\text { ROE bank lebih baik daripada } \\
\text { asuransi }\end{array}$ \\
\hline DAR & 0,4 & $\begin{array}{l}\text { DAR bank lebih tinggi daripada } \\
\text { asuransi }\end{array}$ \\
\hline DER & 8,1 & $\begin{array}{l}\text { DER bank lebih tinggi daripada } \\
\text { asuransi }\end{array}$ \\
\hline
\end{tabular}

Pada selisih rata-rata rasio keuangan PER, PBV, dan EPS, bank lebih baik daripada leasing. Sedangkan selisih rata-rata rasio keuangan $\mathrm{ROA}$ dan $\mathrm{ROE}$ leasing lebih baik daripada bank. Pada selisih rata-rata rasio keuangan DAR dan DER, bank lebih tinggi daripada leasing, karena aktivitas utama bank, yaitu menghimpun dana masyarakat atau berutang untuk kemudian disalurkan kepada pihak yang memerlukan dana.

Pada urutan ketiga, antara perusahaan Bank dan Efek serta Efek dan Leasing yang berbeda signifikan pada 4 dari 9 rasio keuangan. Perusahaan Bank dan Efek berbeda signifikan pada EPS, ROA, DAR, serta DER.

Tabel 13. Ringkasan Selisih Rata-rata Rasio Keuangan EPS, ROA, DAR, DER antara Bank dan Efek Tahun 2007-2010

\begin{tabular}{ccl}
\hline $\begin{array}{c}\text { Rasio } \\
\text { Keuangan }\end{array}$ & $\begin{array}{c}\text { Selisih } \\
\text { Rata-rata }\end{array}$ & \multicolumn{1}{c}{ Keterangan } \\
\hline EPS & 181,6 & $\begin{array}{l}\text { EPS bank lebih baik daripada } \\
\text { efek }\end{array}$ \\
ROA & $-3,6$ & $\begin{array}{l}\text { ROA efek lebih baik daripada } \\
\text { bank }\end{array}$ \\
DAR & 0,2 & $\begin{array}{l}\text { DAR bank lebih tinggi daripada } \\
\text { efek } \\
\text { DER bank lebih tinggi daripada } \\
\text { efek }\end{array}$ \\
\hline
\end{tabular}

Pada selisih rata-rata rasio keuangan EPS, bank lebih baik daripada efek. Sedangkan selisih rata-rata rasio keuangan ROA efek lebih baik daripada bank. Pada selisih rata-rata rasio keuangan DAR dan DER, bank lebih tinggi daripada efek, karena aktivitas utama bank, yaitu menghimpun dana masyarakat atau berutang untuk kemudian disalurkan kepada pihak yang memerlukan dana.

Hasil temuan ini akan diperjelas oleh gambaran yang disajikan pada selisih mean antara perusahaanperusahaan keuangan pada Tabel 14.

Tabel 14. Selisih Mean PER, PBV, EPS, ROA, ROE, DAR, DER, Growth of Revenue, Serta Net Income Growth Tahun 2007-2010

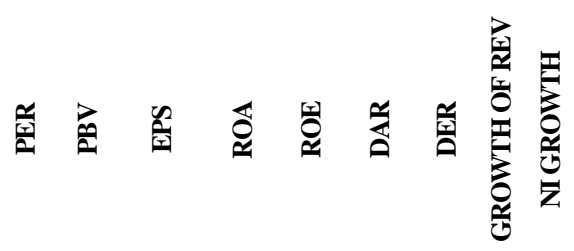

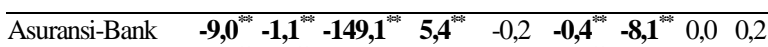

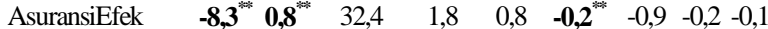

$\begin{array}{llllllllll}\text { Asuransi-Leasing } & -2,1 & \mathbf{0 , 5 ^ { * * }} & 6,0 & \mathbf{- 5 , 5 ^ { * * * }} & -6,5 & -0,0 & 0,6 & -0,1 & 0,2\end{array}$

$\begin{array}{llllllllll}\text { Bank-Efek } & 0,7 & 0,3 & \mathbf{1 8 1}, \mathbf{6}^{* *} & \mathbf{- 3 , \mathbf { 6 } ^ { * * }} & 1,0 & \mathbf{0 , 2} & \mathbf{7 , 2 ^ { * * }} & 0,2 & -0,4\end{array}$

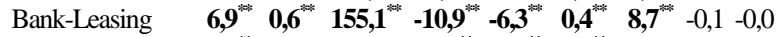

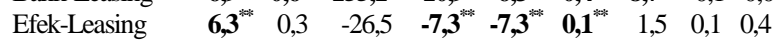

$*$ = signifikan pada tingkat $10 \%$

$* *=$ signifikan pada tingkat $5 \%$

Keterangan: cetak tebal menunjukkan adanya perbedaan yang signifikan antar perusahaan keuangan tersebut.

Tabel 11 menunjukkan bahwa rasio-rasio keuangan yang memiliki perbedaan yang signifikan, secara deskriptif memiliki selisih mean yang relatif besar. Sedangkan rasio-rasio keuangan yang tidak memiliki perbedaan yang signifikan memiliki selisih mean yang relatif kecil.

Selisih Mean rasio keuangan PER terbesar dan signifikan terdapat antara Perusahaan Asuransi dan Perusahaan Bank dengan besaran -9,0. Hal ini bermakna secara rata-rata PER Perusahaan Bank lebih besar 9,0 poin dari Perusahaan Asuransi. Sedangkan selisih Mean terkecil terdapat antara Perusahaan Bank dan Perusahaan Efek.

Selisih Mean rasio keuangan $P B V$ terbesar dan signifikan terdapat antara Perusahaan Asuransi dan Perusahaan Bank dengan besaran 1,1. Hal ini bermakna secara rata-rata $P B V$ Perusahaan Asuransi lebih besar 1,1 poin dari Perusahaan Bank. Sedangkan selisih Mean terkecil dan tidak signifikan terdapat antara Perusahaan Bank - Perusahaan Efek serta Perusahaan Bank - Perusahaan Leasing.

Selisih Mean rasio keuangan EPS terbesar dan signifikan terdapat antara Perusahaan Bank dan Perusahaan Efek dengan besaran 181,6. Hal ini 
bermakna secara rata-rata EPS Perusahaan Bank lebih besar Rp. 181,6 dari Perusahaan Efek. Sedangkan selisih Mean terkecil dan tidak signifikan terdapat antara Perusahaan Asuransi dan Perusahaan Leasing.

Selisih Mean rasio keuangan $R O A$ terbesar dan signifikan terdapat antara Perusahaan Bank dan Perusahaan Leasing dengan besaran 10,9. Hal ini bermakna secara rata-rata ROA Perusahaan Bank lebih besar 10,9 poin dari Perusahaan Leasing. Sedangkan selisih Mean terkecil dan tidak signifikan terdapat antara Perusahaan Asuransi dan Perusahaan Efek.

Selisih Mean rasio keuangan $R O E$ terbesar dan signifikan terdapat antara Perusahaan Efek dan Perusahaan Leasing dengan besaran $-7,3$. Hal ini bermakna secara rata-rata $R O E$ Perusahaan Leasing lebih besar 7,3 poin dari Perusahaan Efek. Sedangkan selisih Mean terkecil dan tidak signifikan terdapat antara Perusahaan Asuransi dan Perusahaan Bank.

Selisih Mean rasio keuangan DAR terbesar dan signifikan terdapat antara Perusahaan Bank dan Perusahaan Leasing dengan besaran 0,4. Hal ini bermakna secara rata-rata DAR Perusahaan Bank lebih besar 0,4 poin dari Perusahaan Leasing. Sedangkan selisih Mean terkecil dan tidak signifikan terdapat antara Perusahaan Asuransi dan Perusahaan Leasing.

Selisih Mean rasio keuangan DER terbesar dan signifikan terdapat antara Perusahaan Bank dan Perusahaan Leasing dengan besaran 8,7. Hal ini bermakna secara rata-rata DER Perusahaan Bank lebih besar 8,7 poin dari Perusahaan Leasing. Sedangkan selisih Mean terkecil dan tidak signifikan terdapat antara Perusahaan Asuransi dan Perusahaan Leasing.

Selisih Mean rasio keuangan Growth of Revenue terbesar dan tidak signifikan terdapat antara Perusahaan Bank dan Perusahaan Efek dengan besaran 0,2. Hal ini bermakna secara rata-rata Growth of Revenue Perusahaan Bank lebih besar 0,2 poin dari Perusahaan Efek. Sedangkan selisih Mean terkecil dan tidak signifikan terdapat antara Perusahaan Asuransi dan Perusahaan Bank.

Hasil uji beda pada PER, PBV, EPS, ROA, ROE, DAR, DER, Growth of Revenue, serta Net Income Growth, menunjukkan bahwa perusahaan Bank memiliki perbedaan signifikan terbanyak terhadap perusahaan Asuransi, Efek, dan Leasing pada sebagian besar dari rasio-rasio keuangan tersebut. Hal ini disbabkan Perusahaan Bank sudah beroperasi di Indonesia lebih lama dibandingkan perusahaan Asuransi, Efek, dan Leasing. Industri Perbankan sudah bagian tak terpisahkan dari kehidupan finansial di Indonesia atau mindset masyarakat Indonesia sudah Bank Minded. Selain itu, sebagian besar Bank yang masuk dalam kriteria populasi mendapat dukungan kinerja di Unit Bisnisnya, yaitu perbankan Syariah. Dukungan dari Unit Bisnis Syariah belum dimiliki oleh perusahaan Efek, dan Leasing. Sedangkan pada perusahaan Asuransi baru mulai merintis Asuransi Syariah pada tahun-tahun terakhir. Selain itu, sebagian perusahaan Bank yang masuk sebagai sampel penelitian, misal Bank Mandiri memiliki potensi untuk terus berkembang menjadi lembaga keuangan (Anggreni, 2010).

Tidak adanya perbedaan kinerja keuangan yang signifikan pada rasio keuangan Growth of Revenue dan Net Income Growth antar perusahaan Asuransi, perusahaan Bank, perusahaan Efek, dan perusahaan Leasing menunjukkan bahwa persaingan antar perusahaan-perusahaan tersebut sangat ketat. Layanan jasa keuangan yang ditawarkan antar dan cara memasarkan produk perusahaan-perusahaan tersebut pada tahun-tahun terakhir ini relatif mirip. Sebagai contoh produk deposito milik Bank berkompetisi dengan produk investasi saham yang ditawarkan perusahaan Efek, juga berkompetisi dengan produk Unit-Link yang dikelola perusahaan Asuransi. Cara pemasaran antar perusahaan Asuransi, perusahaan Bank, perusahaan Efek, dan perusahaan Leasing juga mirip, yaitu menggunakan fasilitas internet banking (Windarto, 2010). Berkaitan dengan hal ini, antar perusahaan tersebut harus mampu memberikan layanan yang khas kepada para customer, sehingga perusahaan-perusahaan tersebut dapat memelihara loyalitas para customer, dengan harapan perusahaan Asuransi, perusahaan Bank, perusahaan Efek, dan perusahaan Leasing mampu meningkatkan kinerja keuangannya.

Selisih Mean rasio keuangan Net Income Growth terbesar dan tidak signifikan terdapat antara Perusahaan Efek dan Perusahaan Leasing dengan besaran 0,4 . Hal ini bermakna secara rata-rata Net Income Growth Perusahaan Efek lebih besar 0,4 poin dari Perusahaan Leasing. Sedangkan selisih Mean terkecil dan tidak signifikan terdapat antara Perusahaan Bank dan Perusahaan Leasing.

\section{SIMPULAN DAN SARAN}

Kinerja keuangan perusahaan asuransi berbeda signifikan dibandingkan dengan kinerja keuangan bank terdapat pada rasio keuangan PER, PBV, EPS, ROA, DAR, dan DER. Sedangkan pada rasio keuangan ROE, growth of revenue, dan net income growth, perusahaan asuransi tidak berbeda signifikan dengan perusahaan bank.

Kinerja keuangan perusahaan asuransi berbeda signifikan dibandingkan dengan kinerja keuangan perusahaan efek pada rasio keuangan PER, PBV, dan DAR. Sedangkan pada rasio keuangan EPS, ROA, $\mathrm{ROE}, \mathrm{DER}$, growth of revenue, dan net income growth, perusahaan asuransi tidak berbeda signifikan dengan perusahaan efek. 
Kinerja keuangan perusahaan asuransi berbeda signifikan dibandingkan dengan kinerja keuangan perusahaan leasing hanya pada rasio keuangan PBV dan ROA. Sedangkan pada rasio keuangan PER, EPS, ROE, DAR, DER, growth of revenue, dan net income growth, kinerja perusahaan asuransi tidak berbeda signifikan dengan perusahaan leasing.

Kinerja keuangan bank berbeda signifikan dibandingkan dengan kinerja keuangan perusahaan efek hanya pada rasio keuangan EPS, ROA, DAR, dan DER. Sedangkan pada rasio keuangan PER, $\mathrm{PBV}$, ROE, growth of revenue, dan net income growth, kinerja bank tidak berbeda signifikan dengan perusahaan efek.

Kinerja keuangan bank berbeda signifikan dibandingkan dengan kinerja keuangan perusahaan leasing pada rasio keuangan PER, PBV, EPS, ROA, ROE, DAR, dan DER. Sedangkan pada rasio keuangan growth of revenue, dan net income growth, kinerja bank tidak berbeda signifikan dengan perusahaan Leasing.

Kinerja keuangan perusahaan Efek berbeda signifikan terhadap kinerja keuangan perusahaan Leasing terdapat hanya pada rasio keuangan PER, ROA, ROE, dan DAR. Sedangkan pada rasio keuangan PBV, EPS, DER, Growth of Revenue, dan Net Income Growth, kinerja perusahaan efek tidak berbeda signifikan dengan perusahaan Leasing.

Kinerja keuangan antar lembaga keuangan tersebut secara umum, yang memiliki perbedaan terbanyak terhadap lembaga keuangan lainnya, yaitu bank. Hal ini disebabkan bank telah beroperasi lama di Indonesia dan telah menjadi bagian tak terpisahkan dari aktivitas bisnis di masyarakat serta memiliki unit bisnis syariah yang memberikan kontribusi pada revenue dan net income bank.

Perusahaan Asuransi Bank, Efek, dan Leasing harus terus berupaya keras untuk memperbaiki kinerja keuangannya. Perusahaan Asuransi yang memiliki rata-rata PBV di bawah satu harus berupaya keras memperbaiki kinerja keuangannya, agar dapat meyakinkan investor dengan senantiasa menyediakan produk yang sesuai dengan kebutuhan dan harapan konsumen.

Penelitian berikutnya dapat lebih fokus untuk menguji apakah kinerja keuangan bank lebih baik daripada asuransi, efek, dan leasing.

\section{DAFTAR REFERENSI}

Anggreni, P. 2010. 100 Emiten Penghasil Laba Terbesar. Investor. XII(208): 86-87.

Badan Pusat Statistik. 2012. Berita Resmi Statistik No. 12/02/Th. XIII, 10 Februari 2010. (http://www. bps.go.id/brs_file/pdb-10feb10.pdf).

Brigham, E. F. \& Daves, P. R. 2010. Intermediate Financial Management. South Western: Thompson.

Bursa Efek Indonesia. 2010. Laporan Keuangan Tahunan. (http://www.idx.co.id/Home/Listed Companies/CompanyProfile/tabid/89/language/i d-ID/Default.aspx)

Darmawan, K. 2010. Masih Ada Asa di Bursa. Investor. XII(208): 29-36.

Groose, R. 2004. The Future Financial Services. Blackwell Publishing Ltd. (http://books.google. co.id/books?id=Y9V81-cW2UEC\&dq=The+

Future++ Financial+Services+Blackwell+Publishing\&hl=id\&sa=X\&ei=EBO3UOfRIc2xrAeF _4H4Dg\&ved=0CDMQ6AEwAA, diakses 6 Juni 2011).

Madura, J. 2008. Financial Institutions and Markets. Ohio: Mason.

Meryana, E. 2011. Persaingan Industri Asuransi Ketat. (http://bisniskeuangan. kompas.com/read/2011/ 06/01/11054120/,diakses 1 Juni 2011).

Nuryanti, N. 2010. Industri Sarat Aturan yang Menguntungkan. Investor, XII(208): 98-99.

Rose, P. S. \& Hudgins, S. C. 2008. Bank Management \& Financial Services. New York: McGraw Hill.

Windarto. Oktober 2010. Menjual Asuransi Lewat Telemarketing. Investor. XII(208): 24-25.

World Economic Forum. 2011. The Future of The Global Financial System. (https://membersweforum.org/pdf/scenarios/The/Future of the Global Financial System.pdf, diakses 4 Juli 2011).

Yudha, D. S. \& Nasir, M. 2012. Analisis Pengaruh Intelectual Capital terhadap Kepercayaan dan Reaksi Investor: Studi Kasus Perusahaan yang Terdaftar di Bursa Efek Indonesia. (ejournals1.undip.ac.id/index.php/accounting/article/view /621/620, diakses 23 November 2012) 